\title{
Spatial and Temporal Variation in Ozone and Nitrogen Dioxide in the Seaside Recreation Area Environment
}

\author{
Vaida Vasiliauskienè ${ }^{1}$, Vaida Šerevičienè ${ }^{2 *}$, Aušra Zigmontienè ${ }^{2}$ \\ ${ }^{1}$ Department of Physics, Vilnius Gediminas Technical University \\ ${ }^{2}$ Department of Environmental Protection, Vilnius Gediminas Technical University, \\ Saulètekio ave. 11, LT-10223 Vilnius, Lithuania
}

Received: 18 November 2015

Accepted: 6 January 2016

\begin{abstract}
Our experiment was conducted during the summer (seven days) in the seaside recreation area of $\mathrm{Cu}$ ronian Spit, Lithuania, with a view to observe the dispersion of ozone $\left(\mathrm{O}_{3}\right)$ and nitrogen dioxide $\left(\mathrm{NO}_{2}\right)$ in this territory. In addition, the meteorological parameters (ambient temperature, relative air humidity, wind velocity, and direction) were recorded in order to assess the influence of these parameters on the changes in pollutants in the Curonian Spit. During the experiment, the ozone concentration in the spit varied from 5 to $130 \mu \mathrm{g} / \mathrm{m}^{3}$, while the concentration of nitrogen dioxide varied from 1 to $34 \mu \mathrm{g} / \mathrm{m}^{3}$. It was found that the meteorological parameters influenced the changes in the levels of ozone. The investigation data showed that such meteorological parameters as temperature and relative humidity had the most important influence on ozone concentration variations $(r=0.619(p<0.05) ; r=0.612(p<0.05)$, respectively). The changes in the level of nitrogen dioxide have been mostly influenced by traffic intensity. $\mathrm{O}_{3}$ and $\mathrm{NO}_{2}$ were inversely related. The ozone concentration in Juodkrante and Preila was higher by $37 \%$ than that measured in Klaipeda, while the nitrogen dioxide concentration was lower by $43 \%$. The formation of ozone in the troposphere begins with $\mathrm{NO}_{2}$ photolysis, after which the $\mathrm{NO}$ quickly reacts with ozone to regenerate the $\mathrm{NO}_{2}$.
\end{abstract}

Keywords: ozone, nitrogen dioxide, passive sampler, temperature, relative humidity

\section{Introduction}

The major part of inorganic pollutants is emitted to air from the energy and industrial sectors as well as vehicles $[1,2]$. In the largest cities of Lithuania, motor vehicles generate up to $80 \%$ of all pollutants emitted to the atmosphere; the major part of these pollutants is nitrogen oxides $\left(\mathrm{NO}_{\mathrm{x}}\right)$ [3]. The highest one-hour $\mathrm{NO}_{2}$ concentration in the

*e-mail: vaida.sereviciene@vgtu.lt places where traffic is the most intensive in Lithuania is up to $170 \mu \mathrm{g} / \mathrm{m}^{3}$ [4]. Collections of nitrogen compounds have became one of the most serious ecological problems causing negative local, regional, and global processes [5]. An important source of $\mathrm{NO}_{2}$ is $\mathrm{NO}$ oxidation chemical processes occurring in the atmosphere [6]. As a result of reactions of nitrogen oxides with hydrocarbons occurring in the air due to solar radiation, the strong photochemical oxidants, e.g., ozone, which cause photochemical smog in the lower atmospheric layer, rise [7]. In accordance with 
the requirements of the legislation of the EU and Lithuania $(2008 / 50 / \mathrm{EC})$, the annual limit value $\left(40 \mu \mathrm{g} / \mathrm{m}^{3}\right)$ and onehour limit value $\left(200 \mu \mathrm{g} / \mathrm{m}^{3}\right)$ shall be applied to the nitrogen dioxide $\left(\mathrm{NO}_{2}\right)$ concentration.

Ozone is the most important photochemical oxidant in the troposphere. The most significant variation in ozone concentration takes place in the layer of the troposphere up to 250 meters, i.e., on the ground level of the atmosphere. Ozone is very active in this layer. It participates in the following chemical processes: oxidation, acidification, formation of aerosols, and photochemical smog [8,9]. The ozone level variations mainly depend on the precursor emission characteristics, concentration of different pollutants, and meteorological conditions [10-12]. The surface ozone level in Lithuania is lower if compared with that in Central Europe [13]. The World Health Organization recommends considering $65 \mu \mathrm{g} / \mathrm{m}^{3}$ as the limit value of ozone concentration, since ozone-sensitive plants are damaged when this limit value is exceeded [14]. In Lithuania, such a level of ground-level ozone concentration remains for a third of the vegetation period. Long-term studies carried out in Lithuania show that the ozone concentration exceeding $100 \mu \mathrm{g} / \mathrm{m}^{3}$ in the air of the atmosphere stays approximately for only $9 \%$ of the time [15]. Pursuant to directive 2008/50/EC, the EU member states must inform the public when the one-hour average ozone concentration in the air reaches the limit of $180 \mu \mathrm{g} / \mathrm{m}^{3}$. In order to protect human health, the ozone concentration in the ambient air shall not exceed $120 \mu \mathrm{g} / \mathrm{m}^{3}$ on more than 25 days per calendar year averaged over three years [16].

Meteorological factors have a significant influence on air quality in cities [17]. Calm, mist, drizzle, and temperature inversion (which is mostly observed at night, when the weather is calm and fine) provide favourable conditions for concentrating the pollutants on the ground level of the atmosphere so that air pollution may significantly increase in such cases [18]. Photochemical reactions are the most intensive on sunny and warm days, therefore the highest tropospheric ozone concentrations usually occur during the summer season and at noon [19-21].

The rainy, wet weather with high relative humidity is typically associated with the low ozone levels provided by less intensive photochemical production and, possibly, by ozone deposition on water droplets [22]. Windy weather can influence ozone concentration near the surface in a different way. Strong wind disperses air pollutants and decreases the concentrations of ozone precursors, therefore calm days are more favourable for its production [23]. If the ozone chemical budget in the boundary layer is negative, vertical transport transfers ozone-rich air from aloft downwards, and surface ozone concentrations correlate positively with wind speed [24]. The changes in

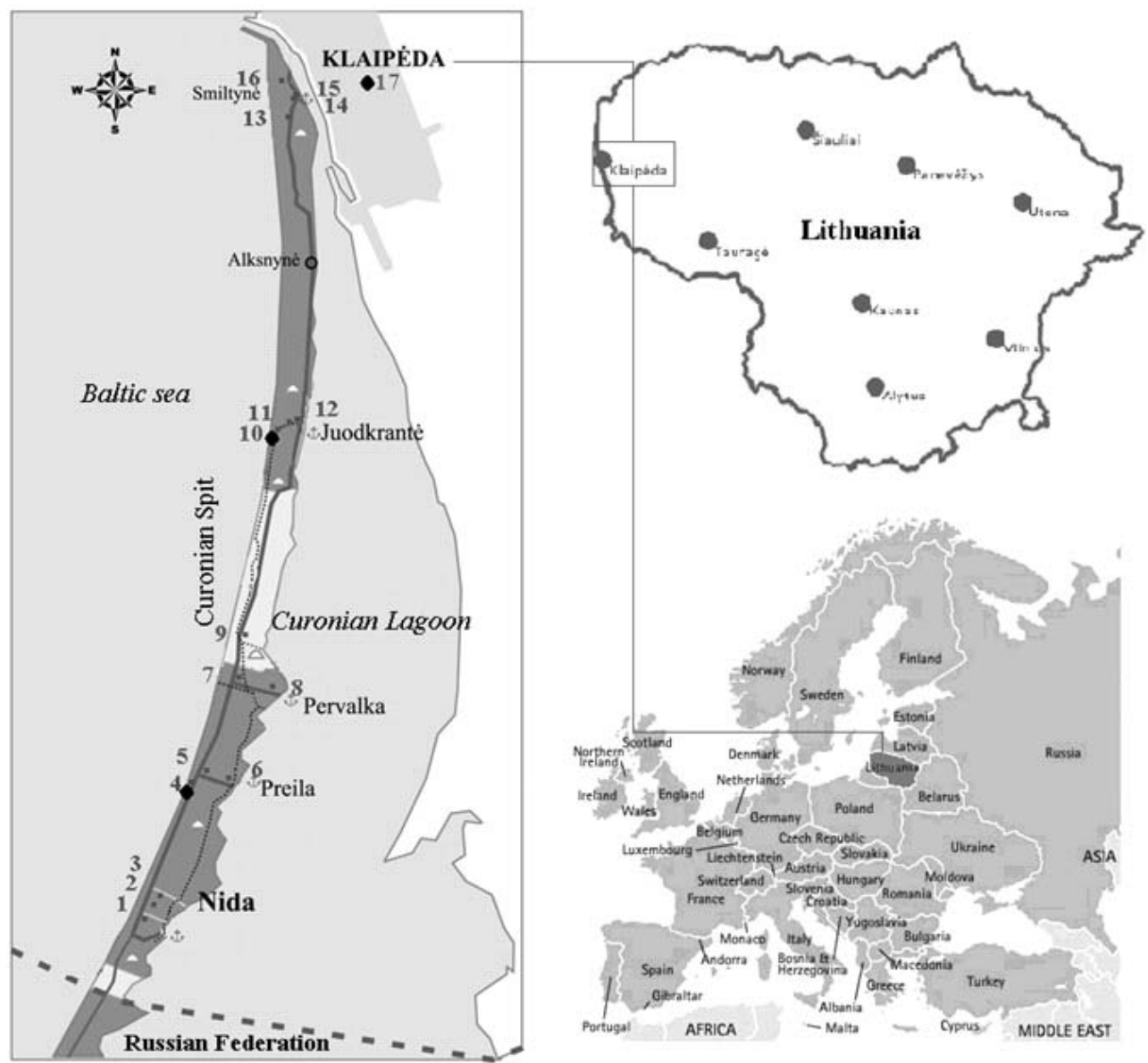

Fig. 1. Location of the study site (Curonian spit, Lithuania). 
Table 1. Basic characteristics of the experimental site.

\begin{tabular}{|c|c|c|c|}
\hline $\begin{array}{l}\text { Sampling } \\
\text { site No. }\end{array}$ & Site & Pollutant & Coordinates \\
\hline 1 & \multirow{3}{*}{ Nida } & $\mathrm{NO}_{2}$ & $\begin{array}{l}55^{\circ} 18,096^{\circ} \\
20^{\circ} 58,814^{\prime}\end{array}$ \\
\hline 2 & & $\mathrm{NO}_{2}$ & $\begin{array}{l}55^{\circ} 18,361^{\circ} \\
20^{\circ} 59,155^{\circ}\end{array}$ \\
\hline 3 & & $\mathrm{NO}_{2}$ & $\begin{array}{l}55^{\circ} 18,722^{\circ} \\
20^{\circ} 59,536\end{array}$ \\
\hline 4 & \multirow{3}{*}{ Preila village } & $\mathrm{NO}_{2}, \mathrm{O}_{3}$ & $\begin{array}{l}55^{\circ} 22,575^{\circ} \\
21^{\circ} 01,842\end{array}$ \\
\hline 5 & & $\mathrm{NO}_{2}$ & $\begin{array}{l}55^{\circ} 22,590^{\circ} \\
21^{\circ} 02,163\end{array}$ \\
\hline 6 & & $\mathrm{NO}_{2}$ & $\begin{array}{l}55^{\circ} 22,384^{\circ} \\
21^{\circ} 03,801^{\circ}\end{array}$ \\
\hline 7 & \multirow{2}{*}{$\begin{array}{l}\text { Pervalka } \\
\text { village }\end{array}$} & $\mathrm{NO}_{2}$ & $\begin{array}{l}55^{\circ} 22,168^{\circ} \\
21^{\circ} 03,919^{\circ}\end{array}$ \\
\hline 8 & & $\mathrm{NO}_{2}$ & $\begin{array}{l}55^{\circ} 24,908^{\circ} \\
21^{\circ} 05,677^{\circ}\end{array}$ \\
\hline 9 & $\begin{array}{l}\text { Pervalka- } \\
\text { Juodkrante } \\
\text { roud }\end{array}$ & $\mathrm{NO}_{2}$ & $\begin{array}{l}55^{\circ} 26,488^{\prime} \\
21^{\circ} 04,311^{\prime}\end{array}$ \\
\hline 10 & \multirow{3}{*}{ Juodkarntė } & $\begin{array}{c}\mathrm{NO}_{2}, \mathrm{O}_{3}, \\
\text { Meteorological } \\
\text { data }\end{array}$ & $\begin{array}{l}55^{\circ} 32,339^{\prime} \\
21^{\circ} 06,037^{\prime}\end{array}$ \\
\hline 11 & & $\mathrm{NO}_{2}$ & $\begin{array}{l}55^{\circ} 32,548^{\circ} \\
21^{\circ} 06,810^{\circ}\end{array}$ \\
\hline 12 & & $\mathrm{NO}_{2}$ & $\begin{array}{l}55^{\circ} 18,172 \\
20^{\circ} 58,824\end{array}$ \\
\hline 13 & $\begin{array}{l}\text { Juodkranté- } \\
\text { Smiltynè } \\
\text { roud }\end{array}$ & $\mathrm{NO}_{2}$ & $\begin{array}{l}55^{\circ} 40,687^{\prime} \\
21^{\circ} 06,789^{\circ}\end{array}$ \\
\hline 14 & \multirow{3}{*}{$\begin{array}{l}\text { Smiltynè } \\
\text { village }\end{array}$} & $\mathrm{NO}_{2}$ & $\begin{array}{l}55^{\circ} 41,798^{\circ} \\
21^{\circ} 07,744^{\circ}\end{array}$ \\
\hline 15 & & $\mathrm{NO}_{2}$ & $\begin{array}{l}55^{\circ} 41,136^{\circ} \\
21^{\circ} 07,816^{\circ}\end{array}$ \\
\hline 16 & & $\mathrm{NO}_{2}$ & $\begin{array}{l}55^{\circ} 41,716^{\prime} \\
21^{\circ} 07,236^{\prime}\end{array}$ \\
\hline 17 & Klaipėda & $\mathrm{O}_{3}$ & $\begin{array}{l}55^{\circ} 41,246^{\circ} \\
21^{\circ} 10,457^{\circ}\end{array}$ \\
\hline
\end{tabular}

the level of ozone concentration are mostly influenced by such meteorological factors as ambient temperature, relative air humidity and wind velocity, while pressure and rainfall have a less significant effect on variations of ozone concentration. The strongest correlation of ground-level ozone production with ambient temperature has been observed, the positive correlation coefficient has been found between these parameters, while the correlation between ozone production and wind velocity and direction, pressure, and cloud abundance is weaker and negative [25, 26]. In Europe, the highest ozone concentrations take place in summer under stable high-pressure systems with clear skies [15]. Major meteorological elements affecting the concentration of nitrogen oxides in the air are wind direction, wind velocity, air temperature and relative air hu- midity [27]. Laurinavičienè [28] has noticed that changes in the level of nitrogen dioxide concentration mostly depend on wind velocity and rainfall rather than on temperature.

Nitrogen dioxide $\left(\mathrm{NO}_{2}\right)$ is a very dangerous pollutant due to its high toxicity [29]. Nitrogen oxides and ozone strongly sensitize lungs. Both wet and dry nitrogen dioxide emissions are harmful because they destroy plants and deteriorate the quality of soil, building materials, and water bodies [30]. When nitrogen dioxide enters the human body, it irritates the respiratory tract and may result in breathing difficulties when nitrogen dioxide concentration in the air meets $140 \mu \mathrm{g} / \mathrm{m}^{3}$. Exposure to nitrogen dioxide usually results in bronchitis, pneumonia, asthma, chronic obstructive pulmonary disease, etc., in humans [31].

It is known that ozone has a negative effect on metals, building materials, rubber, polymeric materials, lacquered materials, etc. [32]. Ozone also has a negative impact on plants, animals, and human health [11]. It is believed that the cereal crop has decreased by $5-10 \%$ due to the effect of ozone in Lithuania. Ozone may cause respiratory failure, a dry cough, pain when inhaling deeply, chest aches, and sometimes even nausea in humans [33, 34].

Variation in ozone and nitrogen dioxide concentrations was analysed in the Curonian Spit, in the western part of Lithuania.

The Curonian Spit is in western Lithuania and covers Neringa and Klaipeda Municipalities. There is the Baltic Sea to the west and the Curonian Lagoon to the east of the Curonian Spit. To the south lies the state border of the Republic of Lithuania with the Russian Federation. Neringa Municipality is unique, since its entire territory is in the territory of Curonian Spit National Park, which is included in the UNESCO World Heritage List. Significant economic activities are not allowed due to the exclusivity of the territory. Agricultural activity also is not performed because the purpose of forests is recreational and environmental. One of the most influential factors occurring in the described territory is the adverse effect on the environment as well as natural and cultural values in this territory related to increasing urbanization as well as increasing flows of visitors, particularly those of vehicles. Due to identity and exclusivity of the territory, it is necessary to observe the changes in the air quality in this territory.

The goal of our study is to determine the distribution of ozone and nitrogen dioxide concentrations in the investigated seaside recreation area environment and to assess the influence of meteorological parameters on the changes in the levels of these pollutants.

\section{Investigation Methodology}

\section{Sampling Site}

The experiment was carried out in July over seven days. The Curonian Spit is situated in the western part of Lithuania. It is a $98 \mathrm{~km}$ long, thin, curved sand-dune spit that separates the Curonian Lagoon from the Baltic 
Sea coast (Fig. 1). During the experiment, the variation in ozone and nitrogen dioxide as well as meteorological parameters (temperature, relative humidity, wind speed, and direction) was analysed.

The ozone concentration measurements were carried out in Juodkrante at the site which is $\sim 100 \mathrm{~m}$ from the Baltic Sea and $\sim 1.5 \mathrm{~km}$ from the Curonian Lagoon. The data on the ozone concentrations (one-hour average values) received from the Air Monitoring Station located in Klaipeda and the Air Monitoring Station in Preila was used for analysis.

A sampling of $\mathrm{NO}_{2}$ was performed by employing the diffusion tubes. The places near the main road, in the towns and villages of the spit, and in the surrounding area were selected as the measuring sites. In total, 16 sampling sites scattered across the study area of the spit were analysed (Fig. 1, Table 1). In each of the sampling sites, two co-located diffusive samplers of the same type were actively exposed for a period of one week.

\section{Sampling Methodology}

The ozone concentrations in Juodkrante, Preila, and Klaipeda were measured continuously by using the commercial ozone analysers. Functioning of such analysers is based on the principle of ultraviolet absorption. The ozone concentration was measured continuously and the data was presented as a one-hour average. Data were automatically recorded in the computer. The precision of the measurements was $2 \mu \mathrm{g} / \mathrm{m}^{3}$. The range of measurements made by using ozone analysers was $0-2,000 \mu \mathrm{g} / \mathrm{m}^{3}$, while measurement sensitivity was $2 \mu \mathrm{g} / \mathrm{m}^{3}$. The air was sucked through the Teflon lines and the sample flow rate was $1.5 \mathrm{l} / \mathrm{min}$. The analogue signal was converted into a digital signal by means of an ADC-16 converter, which allowed us to monitor data directly using such applications as PicoLog and Microsoft Excel.

Meteorological parameters were observed during the experiment in sampling site No. 10 (Fig. 2, Table 1). Temperature, relative humidity, wind speed, and wind direction were measured using the PC Radio Weather Station, and the data was automatically entered in the computer. The temperature was measured within the range -30.0 to $70^{\circ} \mathrm{C}$ (with accuracy of $\pm 1^{\circ} \mathrm{C}$ ), relative humidity varied within the range $20-100 \%$, wind speed was measured within the range $0-60 \mathrm{~m} / \mathrm{s}$ with an accuracy of $\pm 0.3 \mathrm{~m} / \mathrm{s}$, and wind direction resolution was $5^{\circ}$.

Passive samplers were used for measuring the nitrogen dioxide concentration. The Palmes-type diffusion tube for nitrogen dioxide is a passive device requiring no power for its operation. It collects $\mathrm{NO}_{2}$ by means of molecular diffusion, which takes place along the inert tube to an absorbent (in this case, triethanolamine (TEA)). The sampler consists of a polypropylene tube $(21 \mathrm{~mm}$ internal diameter and $34 \mathrm{~cm}$ long) and stainless steel wire mesh. During preparation of the diffusive tubes, the stainless steel meshes were impregnated with a $20 \%$ solution of TEA in water. In the sampling site, the samplers were mounted vertically, and the lower plug was removed at the onset of sampling in order to allow $\mathrm{NO}_{2}$ to be transported by molecular diffusion upwards the tube to the TEA where it is retained. The plug was replaced at the end of sampling, and the exposed sampler was transported to the laboratory for further analysis. The collected pollutant was determined spectrophotometrically by applying the Saltzmann method.

During transportation and forwarding for analysis, the samplers were sealed. Special care was taken at all times when handling the passive samplers. All samplers were kept in airtight bags during transportation to and from the

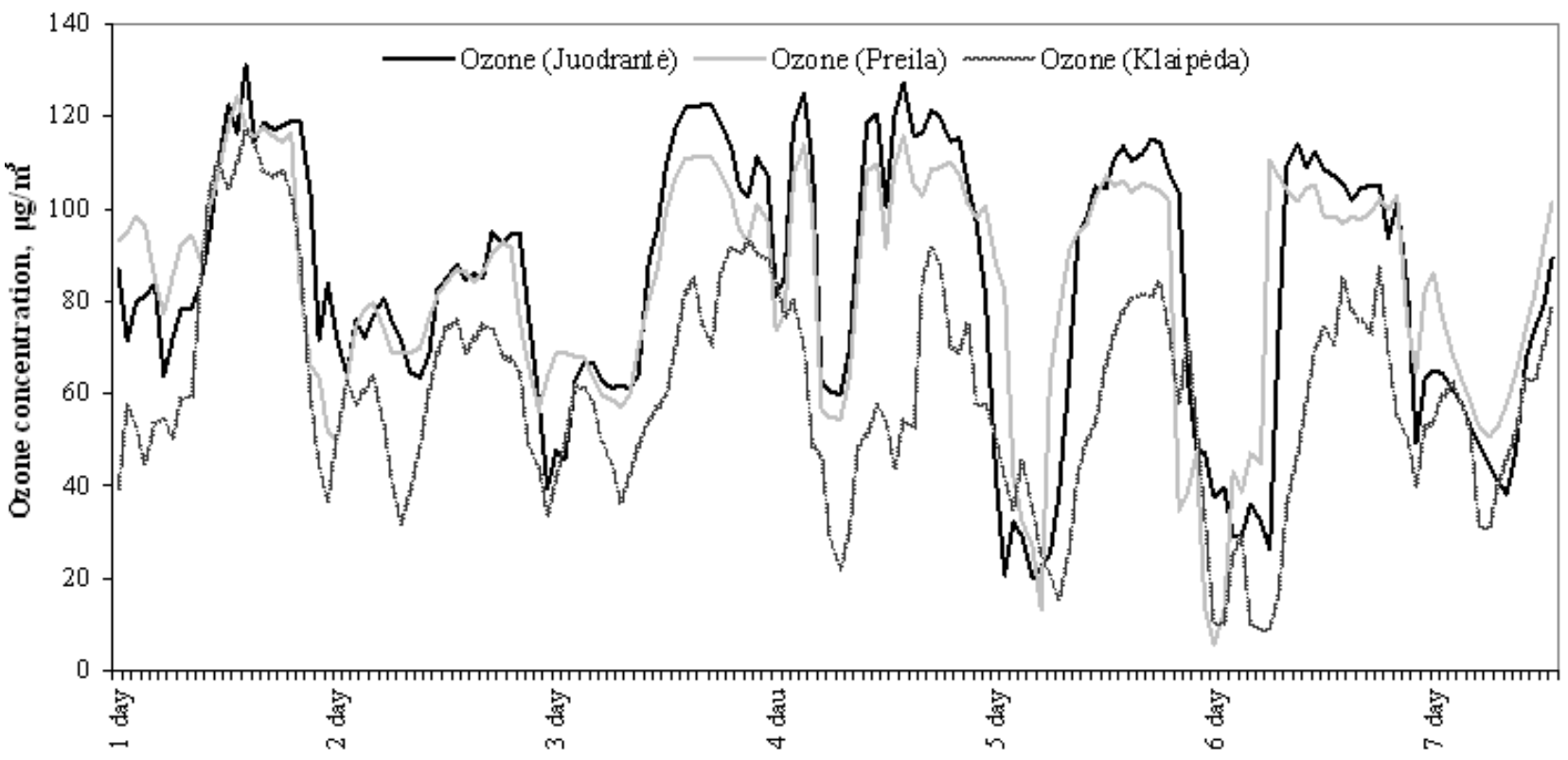

Fig. 2. Variations in ozone concentration (Juodrantè, Preila, Klaipėda), July 11-17, 2010. 
Table 2. Pearson correlations coefficient between $\mathrm{O}_{3}$ (three different sites) and meteorological data. $T$ - temperature, $R H-$ relative humidity, $W_{s}$ - wind velocity, $W_{d}$ - wind direction. Marked correlations are significant at $p<0.05$.

\begin{tabular}{|c|c|c|c|c|c|c|c|}
\hline & $\mathrm{O}_{3}$-Juodkrante் & $\mathrm{O}_{3}$-Preila & $\mathrm{O}_{3}$-Klaipéda & $T$ & $R H$ & $W_{s}$ & $W_{d}$ \\
\hline $\mathrm{O}_{3}$-Juodkrantė & 1,000 & & & & & & \\
\hline $\mathrm{O}_{3}$-Preila & $\underline{0.785}$ & 1,000 & & & & & \\
\hline $\mathrm{O}_{3}$-Klaipėda & $\underline{0.787}$ & $\underline{0.672}$ & 1,000 & & & & \\
\hline $\mathrm{T}$ & $\underline{0.628}$ & $\underline{0.534}$ & $\underline{0.695}$ & 1,000 & & & \\
\hline $\mathrm{RH}$ & $\underline{-0.633}$ & $\underline{-0.517}$ & $\underline{-0.685}$ & $\underline{-0.943}$ & 1,000 & & \\
\hline $\mathrm{W}_{\mathrm{v}}$ & $\underline{0.249}$ & $\underline{0.267}$ & $\underline{0.238}$ & $\underline{0.236}$ & $\underline{-0.294}$ & 1,000 & \\
\hline $\mathrm{W}_{\mathrm{d}}$ & 0.089 & 0.070 & 0.113 & 0.096 & -0.063 & 0.010 & 1,000 \\
\hline
\end{tabular}

field. After exposure, the samplers were kept in the refrigerator until preparation for analysis. In order to protect the samplers from meteorological factors and to reduce the effects of wind, special casings were installed at the measuring sites. The bottom of the casing was left open to ensure entry of air into the sampler. For security reasons and in order to represent the near-human exposure dimension, the samplers in casings were fixed at $3.5 \mathrm{~m}$ above the ground. The area selected for exposure of the samplers was open, free from any buildings, trees and other objects (at least 1 $\mathrm{m}$ from any structures that could disrupt airflow).

\section{Statistical Data Processing and Quality Assurance}

All ozone analysers were calibrated at the beginning of research. During the testing period two unopened control samplers intended for determining nitrogen dioxide were left in the storage location (in a cool dark place). In addition, during the testing period two unopened samplers were transported for the purposes of control of the process of samplers' transportation. After the sampling period, both the control samplers and those that have been exposed were forwarded for laboratory analysis.

Statistical data analysis was performed using such applications as Microsoft Excel, STATISTICA 8.0, and MapViewer. The results including the mean values with the values of standard deviations were represented graphically.

\section{Results and Discussion}

\section{Variation of Ozone Concentration in the Curonian Spit}

Dynamics of the ozone concentration and the influence of meteorological parameters on the changes in the level of this pollutant in the Curonian Spit were analysed for seven days. Variation of ozone concentration is presented in Fig. 2.

During the study, the changes in ozone concentration were analysed in two sites (Juodkrante and Preila) and in
Klaipeda. During the study period, the ozone concentration varied from 20 to $130 \mu \mathrm{g} / \mathrm{m}^{3}$ in Juodkrante, within the range of $5-124 \mu \mathrm{g} / \mathrm{m}^{3}$ in Preila, and within the range of 9-124 $\mu \mathrm{g} / \mathrm{m}^{3}$ in Klaipeda. The measured values of the ozone concentration in Preila and Juodranté (sampling site Nos. 4 and 10) were very similar. These sampling sites are under the influence of climatic conditions of the Baltic Sea; both of them are far away from a major traffic road and are separated by a distance of $15 \mathrm{~km}$. The difference between the average ozone concentration in Preila and Juodkrante (sampling site Nos. 4 and 10) and the average concentration measured in Klaipeda (sampling site No. 17) was statistically significant $(\mathrm{p}<0.05)$. The ozone concentrations in Juodkrante and Preila were higher by $37 \%$ than that measured in Klaipeda, while nitrogen dioxide concentration was lower by $43 \%$ (Fig. 3). Such a distribution of ozone concentration in Klaipeda could be determined by the fact that this site is close to the road where traffic is more intensive. It is known that traffic is the main source of nitrogen dioxide [3]. This significant increase of ozone in the Curonian Spit could be attributed to the decrease of $\mathrm{NO}_{\mathrm{x}}$ emissions, particularly NO. Under the lower NO concentrations, less ozone is consumed to oxidize this pollutant into $\mathrm{NO}_{2}[7,11]$.

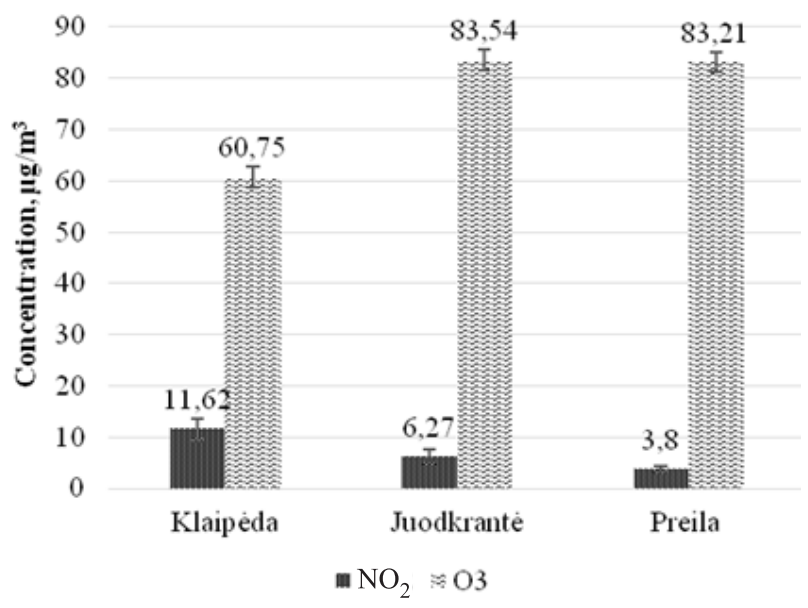

Fig. 3. Different average concentrations of ozone and nitrogen dioxide in the Curonion Spit and Klaipeda. 


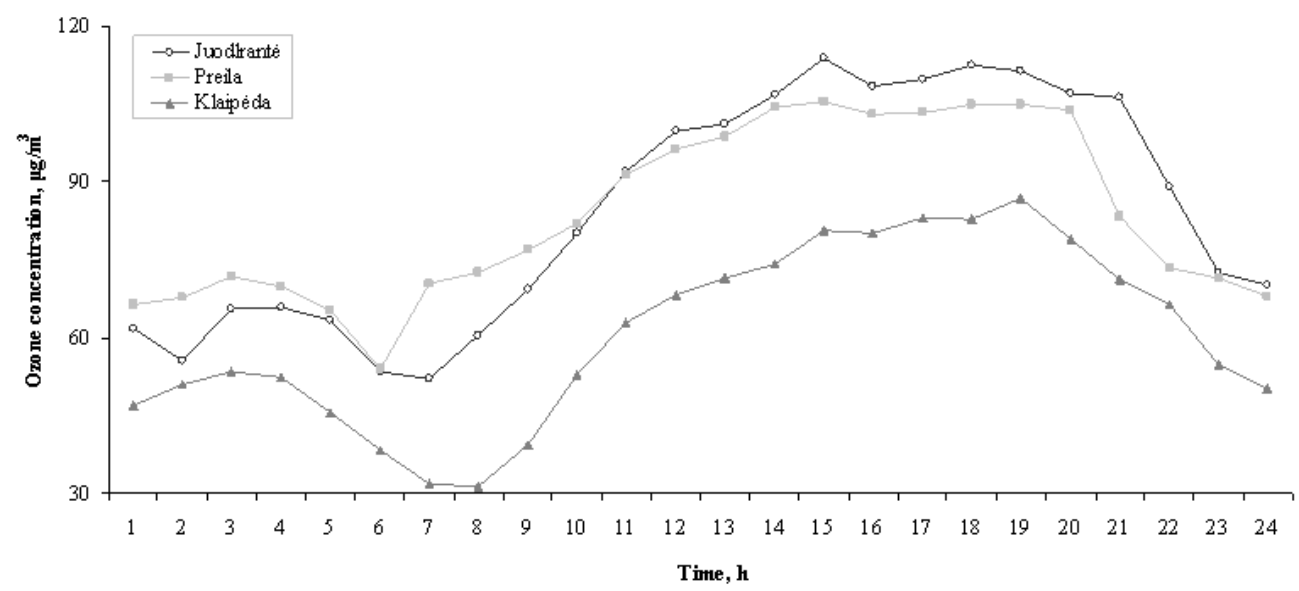

Fig. 4. Variations of daytime average ozone concentrations in the Curonion Spit and Klaipeda.

Highly expressed diurnal variations of ground-level ozone concentration are common. Diurnal variations in ozone show a single peak (Fig. 4). The ozone concentrations reach a minimum value before sunrise, around 6-7 a.m. Along with increases in solar radiation and temperature, photochemical reactions become more active, ozone concentrations begin to increase, and they peak around 3-7 p.m. Higher temperature and stronger solar radiation pro-

a)

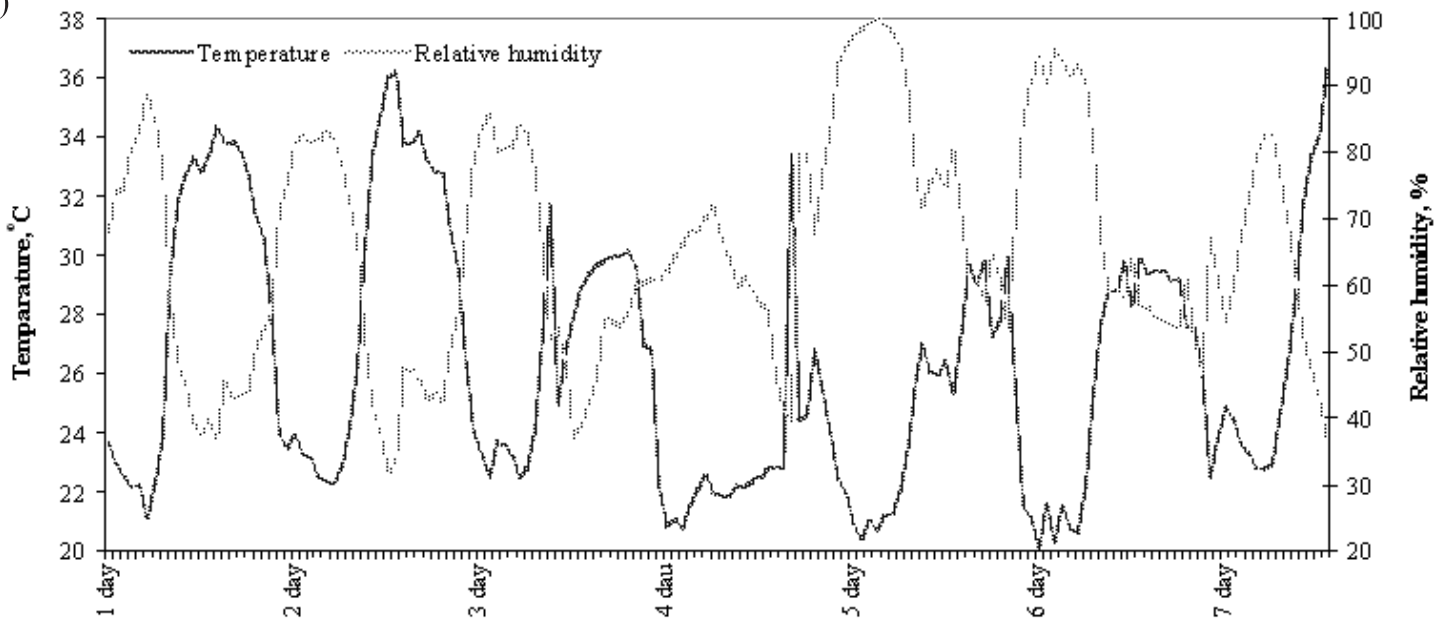

b)

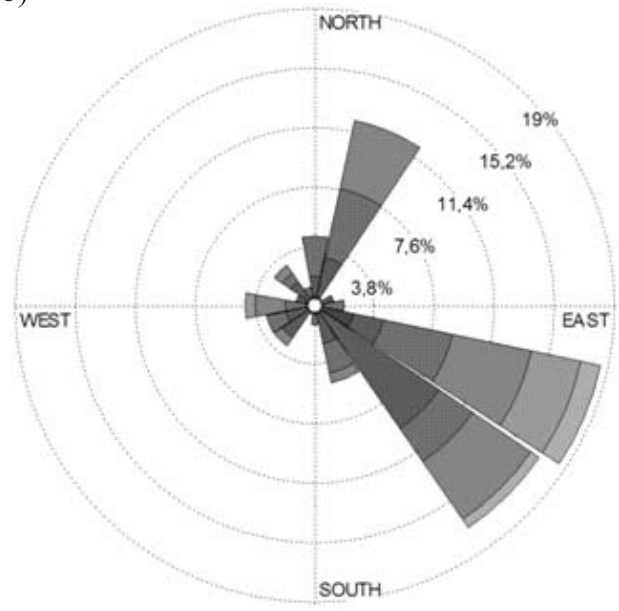

c)

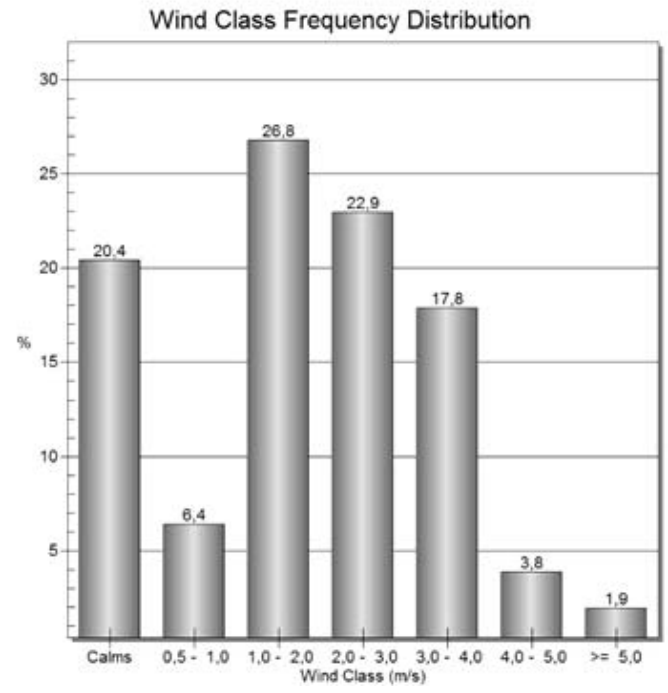

Fig. 5. a)Temperature and relative humidity, b) wind speed, and c) direction in the Curonian Spit. 
Table 3. Traffic intensity in the research area.

\begin{tabular}{|c|c|c|}
\hline $\begin{array}{c}\text { Traffic } \\
\text { intensity }\end{array}$ & $\begin{array}{c}\text { Description of traffic } \\
\text { intensity }\end{array}$ & $\begin{array}{c}\text { Exposure sites of } \\
\text { passive samplers }\end{array}$ \\
\hline 1 & Low traffic intensity & $2,4,11$ \\
\hline 2 & $\begin{array}{c}\text { Average traffic } \\
\text { intensity }\end{array}$ & $3,5,6,8,10$ \\
\hline 3 & Intensive traffic & $1,7,9,12,13,16$ \\
\hline 4 & Very intensive traffic & 14,15 \\
\hline
\end{tabular}

mote formation of $\mathrm{O}_{3}$ and lead to the peak of concentration.

Previous studies [22, 35-37] have shown and our research confirmed that the diurnal ozone cycle consists of four phases:

1) Concentrations of ozone and its precursors decrease slowly, with ozone concentrations low and precursor concentrations high compared with those during the daytime.

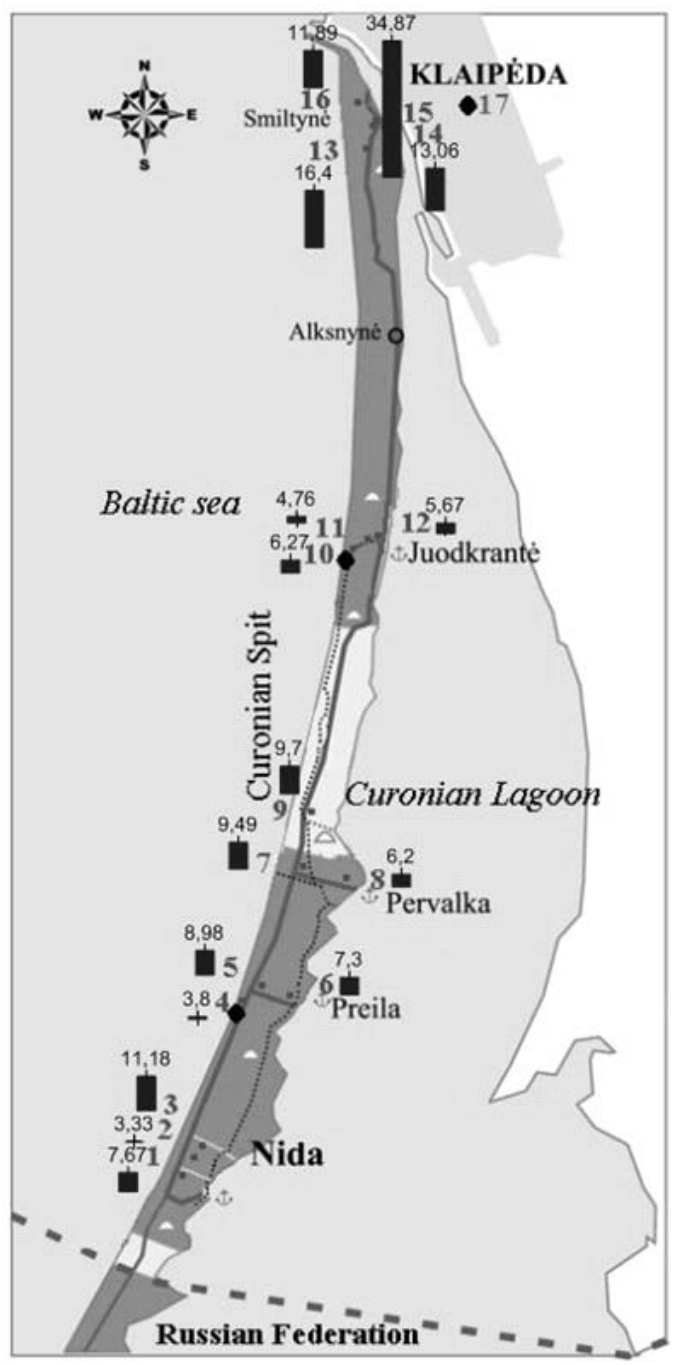

Fig. 6. The change in $\mathrm{NO}_{2}$ concentration variation on the Curonian Spit as investigated by diffusive samplers.
2) As a result of the morning peak traffic, the concentration of NO increases rapidly, but solar radiation is still weak during this period, indicating that ozone concentration decreases due to the reaction with NO.

3) Around 9 a.m., due to the increases in solar radiation and temperature, ozone forms through photolysis of $\mathrm{NO}_{2}$; additionally, atmospheric vertical diffusion is active during this period; thus, ozone at high altitudes is transported to the ground, leading to increased concentrations of ozone.

4) Concentration of ozone decreases rapidly due to the decrease in solar radiation and reaction with NO during the evening peak traffic.

The analysis of meteorological parameters (temperature, relative humidity, wind speed, and direction) was performed for assessing ozone and nitrogen dioxide dispersion peculiarities on the Curonian Spit. The changes of meteorological parameters are presented in Fig. 5.

During the experiment, the temperature varied from 20 to $36^{\circ} \mathrm{C}$, while the relative humidity varied from 32 to $100 \%$. The maximum relative humidity was determined before the sunrise when the lowest air temperature was recorded. During the study period, the wind direction was variable. The low-speed winds were dominant, and wind speed higher than $4 \mathrm{~m} / \mathrm{s}$ was recorded only for $6 \%$ of the entire time; calm was recorded for $20 \%$ of the time, and $1-4 \mathrm{~m} / \mathrm{s}$ wind blew for $68 \%$ of the time. During the study period, the direction of prevailing wind was southeast, toward the sea side $(35 \%)$.

Each meteorological factor plays a unique role in explaining variations in ozone through its own particular response or effect $[12,25]$. The correlation coefficient (r) between ozone concentration and meteorological factors was calculated (Table 2). Ozone concentrations increase with increasing temperatures $(r=0.619, \mathrm{p}<0.05)$, whereas humidity has a different impact on concentration of ozone, i.e., the calculated correlation coefficient was negative $(r=-0.612, \mathrm{p}<0.05)$. Higher humidity levels are usually associated with greater cloud abundance and atmospheric instability, the photochemical process is slowed, and ground-level ozone is depleted [25]. A weak correlation was found between ozone concentration and wind speed as well as direction. Gong [17] has indicated that the in-

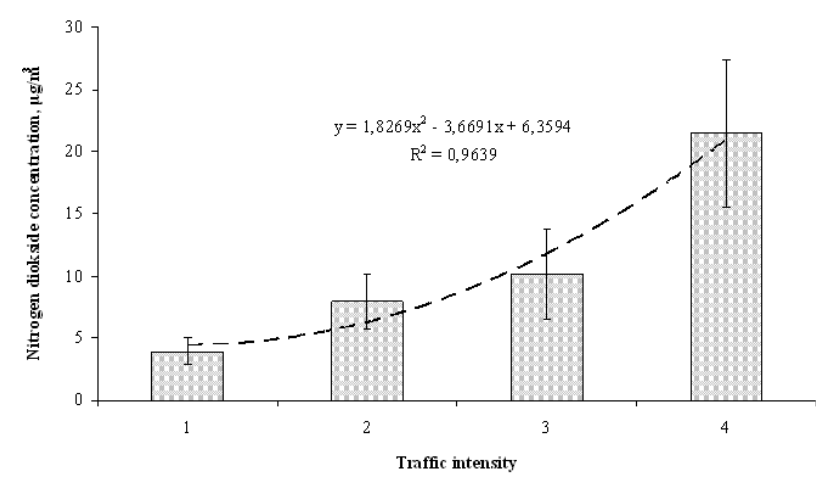

Fig. 7. Average concentrations of $\mathrm{NO}_{2}$ in different traffic intensities. 
fluence of precipitation, air temperature, surface pressure, water vapour pressure, and sunshine duration on ambient air quality is significant.

\section{Spatial Distribution in $\mathrm{NO}_{2}$ Concentration in the Curonian Spit}

The Curonian Spit is a unique area with an impressive landscape. The increasing number of visitors arriving to the Curonian Spit results in the increased flows of vehicles in the region, which leads to an increase of $\mathrm{NO}_{2}$ air pollution. Fig. 6 shows the levels of $\mathrm{NO}_{2}$ concentration measured using diffusive samplers, i.e., the average concentrations during the exposure period.

$\mathrm{NO}_{2}$ concentration in the Curonian Spit varied from 3 to $30 \mu \mathrm{g} / \mathrm{m}^{3}$. The concentrations determined in Smiltyne were three times higher than those in Juodkrante. The increase was recorded where there is intensive traffic and congestion of vehicles, i.e., near the ferry (exposure site No. 16), and is associated with the emissions of vehicles. In order to assess the transport impact on the changes of $\mathrm{NO}_{2}$ concentration, the flows of car traffic were divided according to four different intensity levels.

In the spit, distribution of $\mathrm{NO}_{2}$ concentration was uneven next to the roads of different traffic intensities. The concentration next to the intensive traffic roads was 5.4 times higher than that next to the low-traffic roads. The highest levels of nitrogen dioxide concentration were determined in Smiltyne, next to the ferry (sampler exposure sites Nos. 14, 15), where not only intensive car traffic but also the ferry boats influence $\mathrm{NO}_{2}$ production.

It has been found that nitrogen dioxide concentration next to the roads of different traffic intensity were distributed during the period of the experiment according to the polynomial law (Fig. 7). The correlation coefficient calculated between nitrogen dioxide concentration and traffic intensity is 0.98 [3].

\section{Conclusions}

In this study we investigated surface ozone and its precursor $\mathrm{NO}_{2}$ concentration variability and trends in the seaside recreation area environment (the Curonion Spit, Lithuania). The average ozone concentration determined in the Curonian Spit during the period of experiment (in July) was $83 \mu \mathrm{g} / \mathrm{m}^{3}$. The ozone concentration in Juodkrante and Preila was higher by $37 \%$ than that measured in Klaipeda, while $\mathrm{NO}_{2}$ concentration was $43 \%$ lower. Such a distribution of ozone concentration in Klaipeda could be explained by the fact that this site is close to a road where traffic is more intensive. It is known that traffic is the main source of $\mathrm{NO}_{2}$. Highly expressed diurnal variations in ground-level ozone concentration are common. The measurements have shown that the diurnal ozone cycle consists of four phases. The ozone concentrations reach a minimum value before sunrise. Due to the increases in solar radiation and temperature, photochemical reactions become more active, ozone concentrations begin to increase, and they peak around 3-7 p.m.

The investigation data showed that meteorological parameters such as temperature and relative humidity had the most important influence on ozone concentration variation. The changes of ozone concentration in the spit were mostly influenced by the relative air humidity $(r=-0.612, \mathrm{p}<0.05)$ and ambient temperature $(r=0.619$, $\mathrm{p}<0.05)$.

During the study period, the nitrogen dioxide concentration determined by applying the passive sampling method in the spit varied within the range 2.15 to $42.05 \mu \mathrm{g} / \mathrm{m}^{3}$. The highest levels of nitrogen dioxide were recorded near roads with the intensive traffic, while the lowest levels of nitrogen dioxide were found in areas far from the flow of cars.

\section{References}

1. BALTRĖNAS P., PALIULIS D., VAIŠKŪNAITĖ R. Experimental investigations and evaluation of pollutant emissions into ambient air by rolling stoch engines. Pol. J. Environ. Stud. 23 (3), 673, 2014.

2. NIAZ Y., ZHOU J., IQBAL M., NASIR A., DONG B. Ambient air quality evaluation: a comparative study in China and Pakistan. Pol. J. Environ. Stud. 24 (4), 1723, 2015.

3. ŠEREVIČIENĖ V., BALTRĖNAS P., BALTRĖNAITĖ E., MARČIULAITIENĖ E., PALIULIS D. Investigation of $\mathrm{NO}_{2}$ Behaviuor in the Temperate Continental Climate Road Environment. Water Air Soil Poll. 225, 2173. 2014.

4. EPA (Environmental Protection Agency). Report on ambient air quality in Lithuania in 2009 assessed in accordance with the requirements of the Council Directives 96/62/EC and 1999/30/EC and the Directives of the European Parliament and the Council 2000/69/EC, 2002/3/EC, 2004/107/EC and 2008/50/EC, Vilnius, 22, 2010.

5. WESTMORELAND E.J., CARSLAW N., CARSLAW D., GILLAH A., BATES E. Analysis of air pollution within a street canyon using statistical and dispersion modelling techniques. Atmos. Environ. 41 (39), 9195, 2007.

6. MAZZEO N.A., VENEGAS L.E., CHOREN H. Analysis of $\mathrm{NO}, \mathrm{NO}_{2}, \mathrm{O}_{3}$ and $\mathrm{NO}^{\mathrm{x}}$ concentrations measured at green area of Buenos Aires City during wintertime. Atmos. Environ. 39, 3055, 2005.

7. HASSAN I.A., BASAHI J.M., ISMAIL I.M., HABEEBULLAH T.M. Spatial distribution and temporal variation in ambient ozone and its associated NOx in the atmosphere of Jeddah City, Saudi Arabia. Aerosol Air Qual. Res. 13, 1712, 2013.

8. LIN M., HOROWITZ L.W., OLTMANS S.J., FIORE A.M., FAN S. Tropospheric ozone trends at Mauna Loa Observatory tied to decadal climate variability. Nat. Geosci. 7, 136, 2014.

9. ZHENG G., PYLE J.A., YOUNG P.J. Impact of climate change on tropospheric ozone and its global budgets. Atmos. Chem. Phys. 8, 369, 2008.

10. STATHOPOULOU E., MIHALAKAKOU G., SANTAMOURIS M., BAGIORGAS H. S. On the impact of temperature on tropospheric ozone concentration levels in urban environments. J. Earth Syst. Sci. 17 (3), 227, 2008.

11. SANTURTUN A., GONZALEZ-HIDALGO J. C., SANCHEZ-LORENZO A., ZARRABEITIA M. T. Surface ozone concentration trends and its relationship with weather types 
in Spain (2001-2010). Atmos. Environ. 101, 10, 2015.

12. JANIK R., KELLEROVA D., SCHIEBER B. Spatial and temporal variations in $\mathrm{O}_{3}$ concentrations in wetern Carpathuan rural mountain environments. Pol. J. Environ. Stud. 24 (5), 2003, 2015.

13. WILSON R.C., FLEMING Z.L., MONKS P.S., CLAIN G., HENNE S., KONOVALOV I.B., SZOPA S., MENUT L. Have primary emission reduction measures reduced ozone across Europe? An analysis of European rural background ozone trends 1996-2005. Atmos. Chem. Phys. 12, 437, 2012.

14. HOLLAWAY M.J., ARNOLD S.R., CHALLINOR A.J., EMBERSON L.D. Intercontinental trans-boundary contributions to ozoneinduced crop yield losses in the Northern Hemisphere. BioGeo. 9, 271, 2012.

15. VALUNTAITĖ V., ŠEREVIČIENĖ V., GIRGŽDIENĖ R. Ozone concentration variation near high-voltage transmission lines. J. Environ. Eng. Landsc. 17 (1), 28, 2009.

16. EC DIRECTIVE. Council Directive 2008/50/EC on ambient air and cleaner air for Europe. 303. OJEU, L152, 44, 2008.

17. GONG J., HU Y., LIU M., BU R., CHANG Y., LI C., WU W. Characterization of Air Pollution Index and its affecting factors in industrial urban areas in Northeastern China. Pol. J. Environ. Stud. 24 (4), 1579, 2015.

18. PSILOGLOU B., LARISSI I., PETRAKIS M., PALIATSOS A., ANTONIOU A., VIRAS L. Case Studies on Summertime Measurements of $\mathrm{O}_{3}, \mathrm{NO}_{2}$, and $\mathrm{SO}_{2}$ with a DOAS System in an Urban SemiIndustrial Region in Athens, Greece. Environ. Monit. Assess. 185 (9), 7763, 2013.

19. KALABOKAS P.D., CAMMAS J.-P., THOURET V., VOLZ-THOMAS A. BOULANGER D., REPAPIS C.C. Examination of the atmospheric conditions associated with high and low summer ozone levels in the lower troposphere over the eastern Mediterranean. Atmos.c Chem. Phys. 13 (1), 10339, 2013.

20. RICHARDS N.A.D., ARNOLD S.R., CHIPPERFIELD M.P., MILES G., RAP A., SIDDANS R., MONKS S.A., HOLLAWAYy M.J. The Mediterranean summertime ozone maximum: global emission sensitivities and radiative impacts. Atmos. Chem. Phys. 13 (5), 2013.

21. HEGARTY J., MAO H., TALBOT R. Synoptic controls on summertime surface ozone in the northeastern United States. J. Geophys. Res. 112 (D14306), 2007.

22. NISHANTH T., PRASEED K.M, SATHEESH KUMAR M.K., VALSARAJ K.T. Analysis of ground level $\mathrm{O}_{3}$ and $\mathrm{NO}_{3}$ measured at Kannur, India. J. Earth Sci. Climate Change 3 (1), 10001111, 2012.

23. FRACZEK W., POSTELNICU D., BYTNEROWICZ A., ČERNY M., VASILE C. GIS as a tool for evaluating air pollution and biological resources of Carpathian forests [in:] Szaro R.C., ytnerowicz A., Oszlányi J. (eds.), Effects of air pollution on forest health and biodiversity in forests of the Carpathian Mountains. Proceedings of the NATO Advanced Research Workshop, Stara Lesna, Slovakia, 22-26 May 2002, NATO Science Series, Series I: Life and Behavioural Sciences, 345, 21, 2002.

24. KALABOKAS P.D., MIHALOPOULOS N., ELLUL R., KLEANTHOUS S., REPAPIS C.C. An investigation of the meteorological and photochemical factors influencing the background rural and marine surface ozone levels in the Central and Eastern Mediterranean. Atmos. Environm. 42 (34), 7894, 2008.

25. CAMALIER L., COX W., DOLWICK P. The Effects of Meteorology on Ozone in Urban Areas and their use in Assessing Ozone Trends. Atmos. Environ. 41 (33), 7127, 2007.

26. DAWSON J.P., ADAMS P.J., PANDIS S.N. Sensitivity of Ozone to Summertime Climate in the Eastern USA: A Modeling Case Study. Atmos. Environ. 41 (7), 1494, 2007.

27. LIN J.-T., LIU Z., ZHANG Q., LIU H., MAO J., ZHUANG G. Modeling uncertainties for tropospheric nitrogen dioxide columns affecting satellite-based inverse modeling of nitrogen oxides emissions. Atmos. Chem. Phys. 12 (24), 12255 , 2012.

28. LAURINAVIČIENĖ D. Nitrogen dioxide concentrations and their relation with meteorologic conditions and some environmental factors in Kaunas. Environ. Res. Engin. Manage. 43 (1), 21, 2008.

29. BASARIC V., DORIC V., BOGDANOVIC V., MITROVIC J., JOVIC J. Effects of traffic on NO2 and PM10 emissions in Novi Sad. Pol. J. Environ. Stud. 23 (5), 1837, 2014.

30. ALVAREZ R., WEILENMANN M., FAVEZ J.Y. Evidence of increased mass fraction of $\mathrm{NO}_{2}$ within real-work $\mathrm{NO}_{x}$ emissions of modern light vehicles - derived from a reliable on line measuring method. Atmos. Environ. 42 (19), 4699, 2008.

31. RAASCHOU-NIELSEN O., JOVANOVIC ANDERSEN Z., SOLVANG JENSEN S., KETZE M., SØRENSEN M., HANSEN J., LOFT S., TJØNNELAND A., OVERVAD K. Traffic air pollution and mortality from cardiovascular disease and all causes: a Danish cohort study. Environ. Health 11 (1), 60, 2012.

32. LOUPA G., CHARPANTIDOU E., KIOUTSIOUKIS I., RAPSOMANIKIS S. Indoor microclimate, ozone and nitrogen oxides in two medieval chuches in Cyprus. Atmos. Environ. 40 (39), 7457, 2006.

33. WESCHLER C.J. Ozone's Impact on Public Health: Contributions from Indoor Exposures to Ozone and Products of Ozone-Initiated Chemistry. Environ. Health Perspect. 114 (10), 1489, 2006.

34. LARSEN S., MATSUBARA S., MCCONVILLE G., POULSEN S., GELFAND E. Ozone increases airway hyperreactivity and mucus hyperproduction in mice previously exposed to allergen. J. Toxicol. Environ. Health Part A, 73 (11), 738, 2010.

35. GAO H.O. Day of week effects on diurnal ozone/NOx cycles and transportation emissions in Southern California. Transportation Res. D - Tr. E. 12 (4), 292, 2007.

36. ZHANG H., WU S., HUANG Y., WANG Y. Effects of stratospheric ozone recovery on photochemistry and ozone air quality in the troposphere. Atmos. Chem. Phys. 14 (8), 4079, 2014.

37. WANG Z., LI Y., CHEN T., CHEN T., ZHANG D., SUN F., WEI Q., DONG X., SUN R., HUAN N., PAN L. Groundlevel ozone in urban Beijing over a 1-year period: Temporal variations and relationship to atmospheric oxidation. Atmos. Res. 164-165, 110, 2015. 
